\title{
FLUCTUATION OF POST-PRANDIAL PLASMA MINERAL LEVEL OF JUVENILE JAPANESE FLOUNDER, Paralichthys olivaceus FED DIETARY PHOSPHORUS AND PHYTASE SUPPLEMENTATION
}

\author{
Asda Laining ${ }^{* \#,}$, Rachmansyah"), Lideman ${ }^{* * x}$, and Shunsuke Koshio****) \\ *) Research Institute for Coastal Aquaculture \\ *) Science of Marine Resources, The United Graduate School of Agricultural Science, \\ Kagoshima University, 1-21-24, Korimoto, Kagoshima 890-8580, Japan \\ Lab. of Aquatic Animal Nutrition, Faculty of Fisheries, Kagoshima University
}

(Received 23 August 2010; Accepted 6 December 2010)

\begin{abstract}
In order to investigate the phytic acid degradation in the gut of post juvenile Japanese flounder, indirect method was carried out by measuring the pre-prandial and postprandial plasma mineral and alkaline phosphatase (ALP) level as well as liver phosphorus content. The experiment was designed into a Randomized Block in which experiment units were grouped according to sampling days at 10,20 and 30 days of feeding time. Experimental diets contained three levels of dietary inorganic phosphorus at $0.0 ; 0.25$ and $0.5 \%$ combined with two levels of dietary phytase at 0 and $2000 \mathrm{FTU} / \mathrm{kg}$ diet. Juvenile Japanese flounder (IBW $=36.2 \mathrm{~g}$ ) were randomly distributed into 6 tanks of a $200 \mathrm{~L}$ capacity with density of 15 fish/tank. Blood sampling was carried out at 0 hour (before feeding or pre-prandial) and at 1, 3, 6 and 12 hour post feeding (post-prandial) time in three sampling days, respectively. Plasma was measured for mineral and ALP levels, while liver was analyzed for P content. The observation showed that fish fed without both dietary IP and phytase supplements had the lowest postprandial plasma IP, Mg and ALP levels during 12-h postprandial period. Plasma IP level at 6 -h post-feeding in groups fed dietary 0.25 and $0.5 \%$ IP were significant higher when diet supplemented with phytase than those without phytase supplement. Peak level of plasma IP in fish fed $0.25 \%$ IP was similar to fish fed $0.5 \%$ with the presence of dietary phytase. At 1 and 3-h post-feeding, plasma Ca level increased in all groups, but significant difference was only observed between group fed diet without both dietary IP and phytase and other groups. Similar to plasma IP level, peak of plasma Mg and ALP concentration occurred in fish fed $0.25 \%$ IP together with phytase, and did not significantly differ from fish fed with $0.5 \%$ IP even when phytase was included in diet.
\end{abstract}

KEYWORDS: phytase, phosphorus, mineral, alkaline phosphatase, Japanese flounder

\section{INTRODUCTION}

Phytase presents widely in plants, certain animal tissues and microorganism particularly fungi. Common plants used as ingredient for fish nutrition such as soybean, canola, maize and wheat contain phytase, but has limited importance due to low activity in the feed ingredients and inactivation by heat treatment during processing (Phillippy, 2001). Thus, de-

\# Corresponding author. Research Institute for Coastal Aquaculture, Jl. Makmur Dg. Sitakka, Maros 90512, South Sulawesi, Indonesia. Tel.: + 62411371544

E-mail address: asdalaining@yahoo.com 
phosphorylation of phytic acid or also called myo-inositol hexakiphosphates (IP6) in the digestive tract of monogastric animals such as chicken, pig and fish is believed mainly due to the supplemented phytase in diet. In addition, the non-enzymatic degradation of IP6 in the stomach can be considered as negligible, because IP6 molecule is very stable when exposed to gastric pH condition (Kemme et al., 1998).

Phytase commonly used in animal diet including fish diet is categorized acid phytase with $\mathrm{pH}$ spectrum varying according to phytase sources. The commercial phytase isolated from Peniophora lycii used in this study has optimal $\mathrm{pH}$ activity at $\mathrm{pH}$ 4.0-5.0 (Pontoppidan et al., 2007) which is in accordance with the $\mathrm{pH}$ of in vitro IP6 degradation occurred at $\mathrm{pH} 5.0$ and 4.0 with less degradation occurring at $\mathrm{pH}$ 3.0. The $\mathrm{pH}$ of the gastrointestinal tract has been reported as one of the most critical parameters for in vivo degradation of IP6. Degradation of phosphorus (P) associated IP6 (phytate-P) is generally thought to proceed during crop digestion in chicken where $\mathrm{pH}$ is in a range of 4.0 to 6.5 (Sarra et al., 1992; Selle \& Ravindran, 2007) and during gastric digestion in pig where the $\mathrm{pH}$ ranges from 2.0-5.0 (Argenzio \& Southworth, 1975; Kemme et al., 2006). In case of fish, it is most likely that degradation of IP6 occurs in stomach since the $\mathrm{pH}$ of stomach is between 2.0 and 4.0 depending on the species. Sugiura \& Ferraris (2004) reported that stomach of rainbow trout filled with feed had $\mathrm{pH}$ of chime around 4 and remained at the same unit even 6-9 $\mathrm{h}$ after feeding. Similarly, stomach $\mathrm{pH}$ of juvenile Japanese flounder after $1 \mathrm{~h}$ feeding was around 4.19 and became alkaline in intestine (Laining et al., 2010a).

Degradation and formation of IP6 during digestion is a subject that has scarcely been touched particularly in case of fish. The direct method to determine the IP6 degradation in fish gut is to collect the digestive contents and then analyze for phytase activity, IP6 and its degradation products. However, one of the difficulties in analyzing these parameters is the limit amount of digestive contents, particularly in small fish to meet the samples need. Alternatively, indirect method to determine the IP6 degradation in fish is to measure the postprandial plasma inorganic $\mathrm{P}$ (IP) concentration and other minerals (Liebert \& Portz, 2007).

Mineral content of diet has been reported to be one of the most critical factors affecting the efficacy of phytase in vivo in poultry Angel et al. (2002) and swine (Seynaeve et al., 2000). However, limit information is available in fish species including our previous study dealing with juvenile tiger puffer (Laining et al., 2010b). In regard to growth performances, dietary $\mathrm{Ca}$ / $P$ ratio of 0.5 or without additional Ca supplement combined with 2000 FTU phytase per kg might be the optimum combination in diet for tiger puffer. Furthermore, dietary phytase and IP levels had shown an independent effect on growth in juvenile red sea bream and interaction effect was found on P digestibility, vertebral $\mathrm{Zn}$ and scale $\mathrm{P}$ content (Laining et al., $2010 c$ ). Based on identical diet used for growth trial in juvenile Japanese flounder, this present study aimed at investigating the degradation of IP6 in the gut of post juvenile Japanese flounder along with corresponding postprandial plasma mineral and alkaline phosphatase (ALP) concentration.

\section{MATERIALS AND METHODS}

\section{Experimental Design}

This experiment was designed into a Randomized Block Design in which experimental units were grouped (blocked) according to the sampling time and the treatments were assigned to the experimental units within the block by random. Sampling was carried out three times in every 10 days for 30 days. Formulation of experimental diet was similar to diet used in the previous study (Table 1). Based on analysis, composition of the experimental diet is presented in Table 2).

\section{Observation on Change of Postprandial Plasma Mineral and ALP level}

Post juvenile Japanese flounder were obtained from a commercial hatchery (Matsumoto Suisan Co., Miyazaki, Japan) and maintained with commercial diet (Higashimaru, Kagoshima, Japan) for one week. Fish with average IBW of $36.2 \mathrm{~g}$ were distributed into a 6 tanks of $200 \mathrm{~L}$ capacity at a density of 15 fish/tank. Each tank was equipped with continuous aeration and supplied with seawater with flow through system ( $2 \mathrm{~L} /$ minutes). Fish were fed the experimental diet twice a day to nearly satiation in the morning at 0800 and in the afternoon at 16 00 . After ten days feeding, in following day blood sampling was carried out at 0 -h (before feeding/ pre-prandial) and at 1, 3, 6 and 12-h 
Table 1. Formulation of experimental diet contained different level of dietary IP and microbial phytase

\begin{tabular}{|c|c|c|c|c|c|c|}
\hline \multirow{2}{*}{$\begin{array}{l}\text { Ingredient s } \\
(\%)\end{array}$} & \multicolumn{6}{|c|}{$\begin{array}{l}\text { Phosphorus }(P) / \text { Phytase level } \\
(P=\text { phytase; NP = non phytase })\end{array}$} \\
\hline & 0/NP & $0 / P$ & $0.25 / N P$ & $0.25 / \mathrm{P}$ & $0.5 / N P$ & $0.5 / P$ \\
\hline Brown fishmeal & 18 & 18 & 18 & 18 & 18 & 18 \\
\hline Krill meal & 10 & 10 & 10 & 10 & 10 & 10 \\
\hline Soybean protein isolated ${ }^{1}$ & 30 & 30 & 30 & 30 & 30 & 30 \\
\hline Dextrin-hydrate & 10 & 10 & 10 & 10 & 5 & 5 \\
\hline$\alpha-S \operatorname{tarch}$ & 5 & 5 & 5 & 5 & 5 & 5 \\
\hline Pollack liver oil & 8 & 8 & 8 & 8 & 8 & 8 \\
\hline HUFA $^{2}$ & 1 & 1 & 1 & 1 & 1 & 1 \\
\hline Activated gluten & 5 & 5 & 5 & 5 & 5 & 5 \\
\hline Vitamin mix $^{3}$ & 4 & 4 & 4 & 4 & 4 & 4 \\
\hline Stay $\mathrm{C}^{4}$ & 0.1 & 0.1 & 0.1 & 0.1 & 0.1 & 0.1 \\
\hline Ca-P-free mineral mix $^{5}$ & 4 & 4 & 4 & 4 & 4 & 4 \\
\hline Sodium monophosphate ${ }^{6}$ & 0 & 0 & 1.1 & 1.1 & 2.2 & 2.2 \\
\hline Calcium carbonate & 0.5 & 0.5 & 0.5 & 0.5 & 0.5 & 0.5 \\
\hline Phytase $^{7}$ & 0 & 0.04 & 0 & 0.04 & 0 & 0.04 \\
\hline Betaine $^{8}$ & 0.2 & 0.2 & 0.2 & 0.2 & 0.2 & 0.2 \\
\hline a-Cellulose & 4.2 & 4.16 & 3.1 & 3.06 & 2 & 1.96 \\
\hline
\end{tabular}

1 Soybean protein isolated obtained from Fuji Pro Company, Tokyo, Japan

2 Poweash A, Oriental Yeast Co, Ltd, Tokyo, Japan

3 Vitamin mixture ( $\mathrm{g} \mathrm{kg}^{-1}$ diet): $\beta$-carotene 0.192 ; vitamin D3 0.019 ; menadione 0.0917 ; $\alpha$-tocopherol acetate 0.77 ; thiamin nitrate 0.115 ; riboflavin 0.385 ; pyridoxine- $\mathrm{HCl} 0.092$; cyanocobalamin 0.00018 ; d-biotin 0.0115; inositol 7.698; nicotinic acid 1.539; Ca-pantothenate 0.5391; folic acid 0.0288; choline chloride 15.738; $\rho$-aminobenzoic acid 0.7665 ; cellulose 2.849

4 L-ascorbyl-Na/Ca (DSM Nutritional Product Ltd, Basel, Switzerland)

${ }_{5}$ Calcium-phosphorus free mineral mixture (g/kg diet): $\mathrm{KCl} 1.856 ; \mathrm{MgSO}_{4} \cdot 5 \mathrm{H}_{2} \mathrm{O}$ 5.067; Fe Citrate 1.098; $\mathrm{Al}(\mathrm{OH}) 30.0069 ; \mathrm{ZnSO}_{4} .7 \mathrm{H}_{2} \mathrm{O} 0.132 ; \mathrm{CuSO}_{4} 0.0037 ; \mathrm{MnSO}_{4} .5 \mathrm{H}_{2} \mathrm{O} 0.029 ; \mathrm{K}(\mathrm{IO} 3) 20.006 ; \mathrm{CoSO}_{4} .7 \mathrm{H}_{2} \mathrm{O}$ 0.037; Cellulose 31.75

6 Wako Pure Chemical Industries, Ltd, Japan

7 Ronozyme P5000, DSM Nutritional Product Ltd, Basel, Switzerland (declared activity $=5000 \mathrm{FTU} \mathrm{g}^{-1}$ product)

8 Attractant $\left(\mathrm{g} \mathrm{kg}^{-1} \mathrm{diet}\right)$ : betaine 2.0

post feeding time (post-prandial). One fish from each tank was taken for blood sampling and sacrificed for liver sample. Following sampling at 20 days and 30 days of feeding time were done accordingly. Blood was immediately centrifuged $\left(4000 \mathrm{rpm}, 10 \mathrm{~min}, 4^{\circ} \mathrm{C}\right)$ to separate the plasma. All samples were stored in $-80^{\circ} \mathrm{C}$ until analysis.

\section{Chemical Analysis}

Analysis of IP, Ca, Mg and ALP in plasma was carried out by using a blood analyzer
(Spotchem ${ }^{\mathrm{TM}}$ EZ SP 4430, Arkray Inc., Kyoto, Japan). Total $P$ in the liver was analyzed according to Lowry \& Lopez (1946).

\section{Statistical Analysis}

Data were statistically analyzed by ANOVA for Randomized Block using SPSS software package (Version 15 for Windows; SPSS Inc., Chicago, IL, USA). Duncan multiple range posthoc test was performed to identify the differences among treatments. The statistical significance was set at $\mathrm{P}<0.05$. 
Table 2. Chemical composition of experimental diet (\%)

\begin{tabular}{|c|c|c|c|c|c|c|}
\hline \multirow{2}{*}{$\begin{array}{l}\text { Chemical } \\
\text { composition }\end{array}$} & \multicolumn{6}{|c|}{$\begin{array}{l}\text { Inorganic } P(I P) / \text { Phyt ase level } \\
(P=\text { phytase; } N P=\text { non phytase })\end{array}$} \\
\hline & OIP/NP & OIP/P & $0.25 I \mathrm{P} / \mathrm{NP}$ & $0.25 I P / P$ & $0.5 I P / N P$ & $0.5 / P$ \\
\hline Moisture & 7.7 & 8 & 7.4 & 8 & 7.3 & 7.3 \\
\hline Crude protein & 48.9 & 49.2 & 48 & 48 & 48.5 & 49 \\
\hline Total lipid & 12 & 12.6 & 12.5 & 12.3 & 12 & 12.3 \\
\hline Ash & 7.1 & 7.2 & 7.9 & 7.9 & 8.6 & 8.6 \\
\hline Phytic acid/IP6 & 0.53 & 0.5 & 0.54 & 0.52 & 0.55 & 0.56 \\
\hline \multicolumn{7}{|l|}{ Mine rals content: } \\
\hline - Total P (\%) & 0.82 & 0.84 & 1.03 & 1.05 & 1.24 & 1.17 \\
\hline - Ca (\%) & 0.87 & 0.82 & 0.78 & 0.87 & 0.84 & 0.83 \\
\hline$-M g(m g / g)$ & 1.71 & 1.66 & 1.4 & 1.54 & 1.6 & 1.5 \\
\hline$-\mathrm{Zn}(\mathrm{mg} / \mathrm{g})$ & 69.14 & 69.01 & 61.4 & 67.25 & 69.57 & 65.87 \\
\hline - $\mathrm{Ca} / \mathrm{P}$ ratio & 0.94 & 0.98 & 0.8 & 0.83 & 0.68 & 0.71 \\
\hline
\end{tabular}

\section{RESULTS AND DISCUSSION}

\section{Result}

\section{Change of postprandial plasma IP, Ca and $\mathrm{Mg}$}

Plasma IP concentration during pre-prandial period and during 12-h postprandial period at three sampling days is presented in Table 3. Mean pre-prandial plasma IP level was significantly higher in two groups fed the optimum level of dietary IP (with and without phytase supplement) compared to other four groups fed lower levels of dietary IP (Figure 1). After feeding, concentrations increased within $1-\mathrm{h}$ and reached the peak concentration at 3 and 6 -h depending on the treatments. Fish fed without both dietary IP and supplemental phytase had the lowest postprandial plasma IP level among groups in all sampling times. Sampling at 6-h post feeding, plasma IP concentration in groups fed dietary IP $(0.25 \%$ and $0.5 \%)$ were significant higher when diet supplemented with phytase than those without phytase supplementation. When dietary phytase was included in the diet, peak concentration was achieved in fish fed $0.25 \%$ IP $(22.2 \mathrm{mg} / \mathrm{dL})$, but did not significantly differ from fish fed $0.5 \%$ IP ( $21.0 \mathrm{mg} / \mathrm{dL}$ ). The 12 -h post-prandial IP levels showed the decreasing peak of $\mathrm{P}$ absorption.

Pre and postprandial plasma Ca levels are shown in Table 4. There was no clear trend on the mean pre-prandial plasma Ca concentra- tion among treatments as illustrated in Figure 2. Sampling at 1 and 3 -h post-feeding showed an increasing Ca level in all groups but significant difference was only observed between group fed diet contained no dietary IP and phytase and another 5 groups. The peak $\mathrm{Ca}$ concentration occurred at 1 and 3 -h after feeding depending on treatments. Decreasing peak of Ca level was shown at 6 and 12 -h post-feeding.

Table 5 presents plasma Mg level during pre-prandial and 12-h post-prandial period. Similar to plasma IP, pre-prandial Mg was significantly higher in groups fed diet with $0.5 \%$ IP at two phytase levels and in group fed $0.25 \%$ IP with phytase compared to other groups fed lower dietary IP. The peak concentration was achieved after 3-h post-feeding except in fish fed diet without both dietary IP and phytase which its peak occurred at 6-h after feeding (Figure 3). The peak Mg concentration was highest in fish fed $0.25 \%$ IP together with phytase but did not significantly differ from two groups fed $0.5 \%$ IP.

Sampling at 10,20, and 30 days of feeding time (as the block) did not significantly affect the pre-prandial and 12-h postprandial plasma $\mathrm{IP}, \mathrm{Ca}$ and $\mathrm{Mg}$.

\section{Change of post-prandial plasma ALP}

Concentration of ALP during pre-prandial and 12-h post-prandial period is shown in Table 


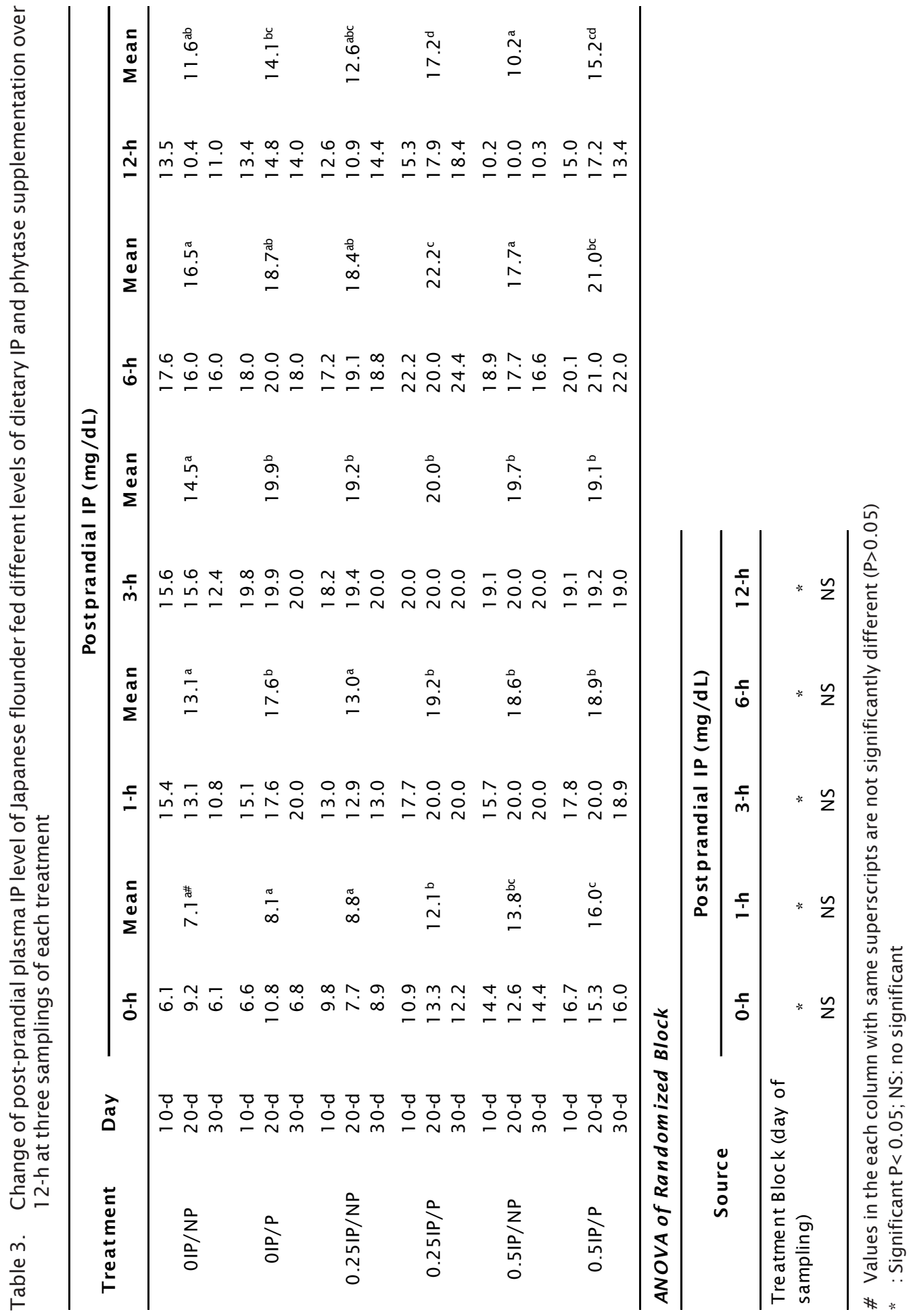



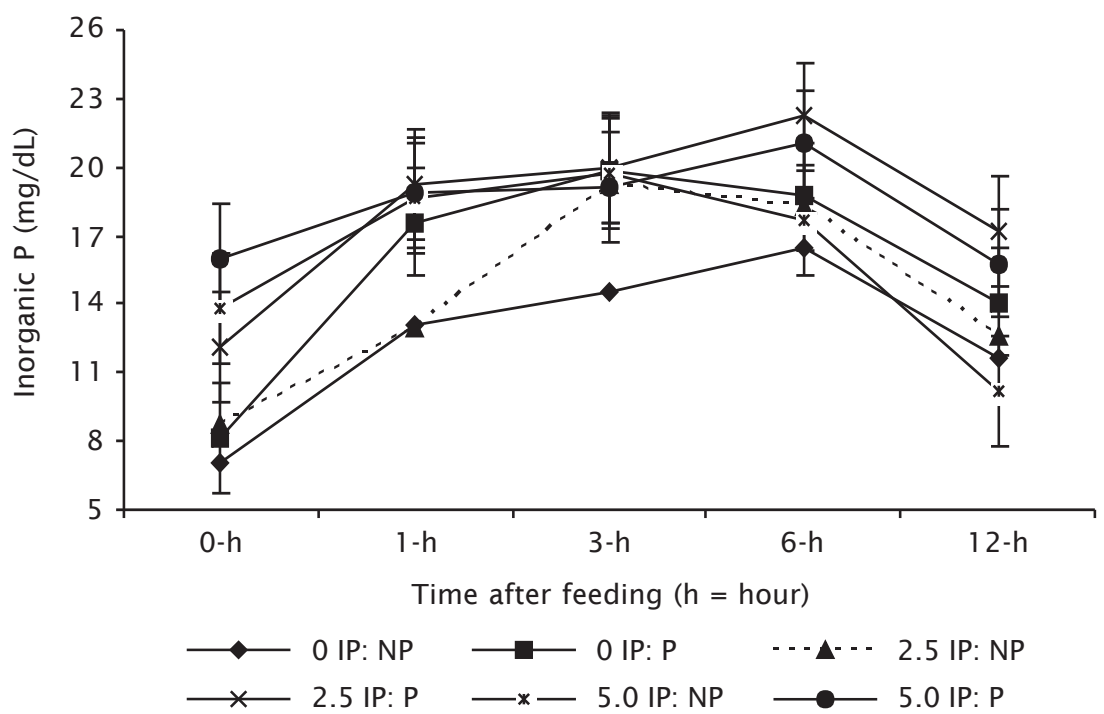

Figure 1. Change of postprandial plasma IP of Japanese flounder fed different levels of dietary IP and phytase supplementation over 12-h. Each point represents the mean values $( \pm \mathrm{SE})$ of three samplings of each treatment

6. Pre-prandial plasma ALP was significantly higher in two groups fed $0.5 \%$ IP than other four groups fed lower level of IP. Generally, fish fed without both dietary IP and phytase supplementation had significantly lower ALP level during 12-h postprandial period as indicated in Figure 4. Increasing of plasma ALP concentration occurred at 1 -h postfeeding except in group fed diet without both IP and phytase supplement. Concentration of ALP achieved the peak at 6 -h post-feeding in all groups except in group fed diet with $0.25 \%$ IP without supplemental phytase. The highest peak of ALP level was in group fed diet with $0.25 \%$ IP and phytase, but did not significantly differ from three other groups (group fed no IP with phytase and two groups fed higher dietary IP of $0.5 \%$ ).

\section{Liver $P$ content at 0,6 , and $12-h$ postprandial}

Change of $\mathrm{P}$ content in liver at pre and 12 $\mathrm{h}$ post-prandial period is presented in Table 7 . Pre-prandial liver P content was not significant different in four groups fed diet without dietary IP and $0.25 \%$ IP at two levels of dietary phytase. However, there was significant different between fish fed no dietary IP and $0.5 \%$ IP. Similar trend was observed at 6 -h post-feeding. At 12 - h post-feeding, concentration of $\mathrm{P}$ in liver was significant higher in fish $0.5 \%$ IP, but did not improve with the presence of phytase in diet.

Based on statistical analysis, there was a significant effect of sampling days on $\mathrm{P}$ liver content in which sampling at 10 days was significant different from sampling at 20 and 30 days.

\section{Discussion}

Incorporation of dietary phytase in fish diets have been reported to improve $P$ availability and growth performances (Rodehutscord \& Pfeffer, 1995; Yan \& Reigh, 2002). However, the observation of the specific effects of phytase in different fish species is insufficient. The result of this present study demonstrated the different effect of dietary IP and phytase levels on concentration of mineral and ALP in plasma as well as liver $P$ content which are further explained by physiological data on the change of 12-h post-prandial of these parameters. Lower plasma IP in fish fed diet without both dietary IP and phytase at pre and 12-h post-prandial period indicated that absorption of IP from this diet in digestive tract of red sea bream was very low compared to other groups. This result revealed that $\mathrm{P}$ originated from or- 


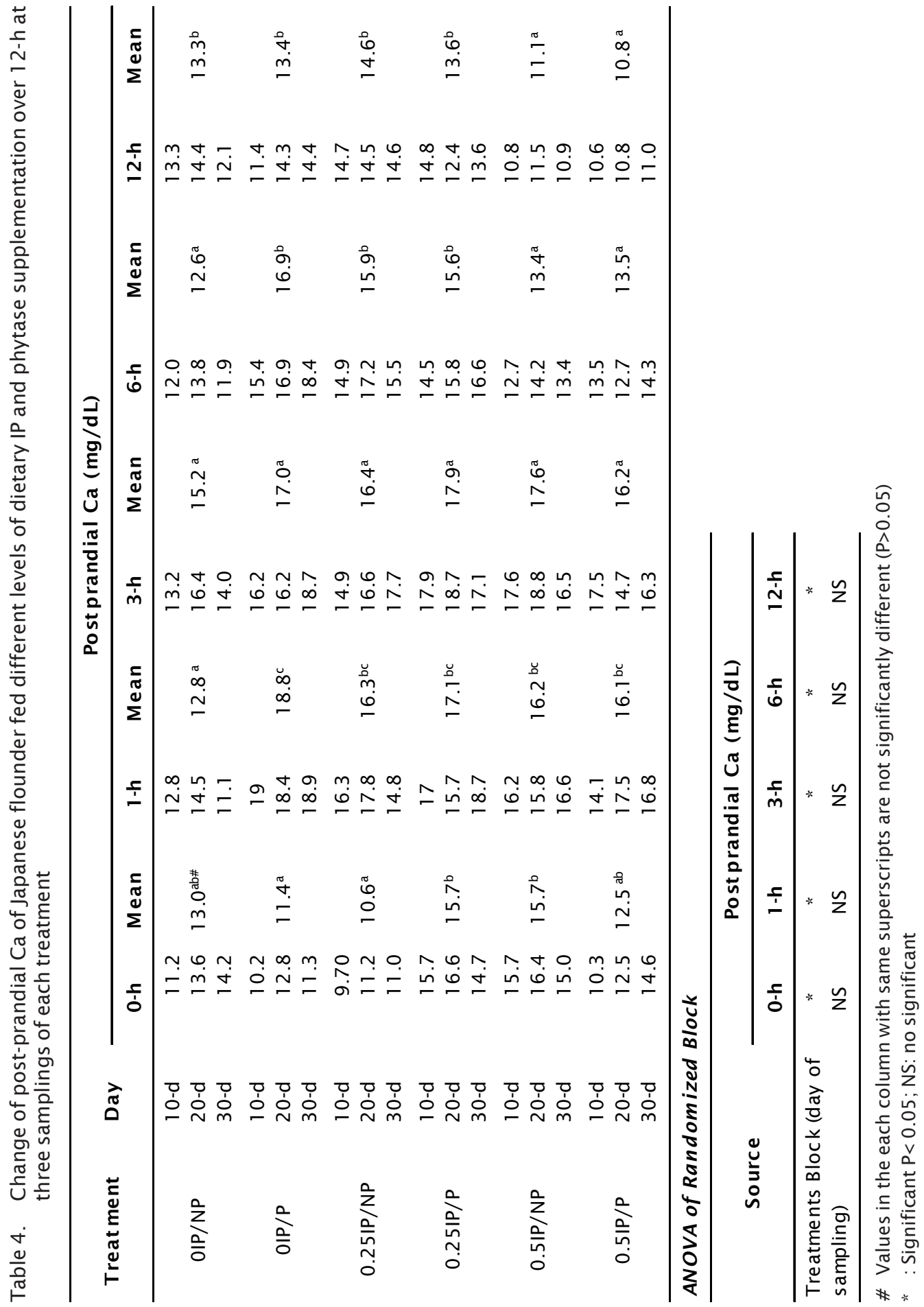




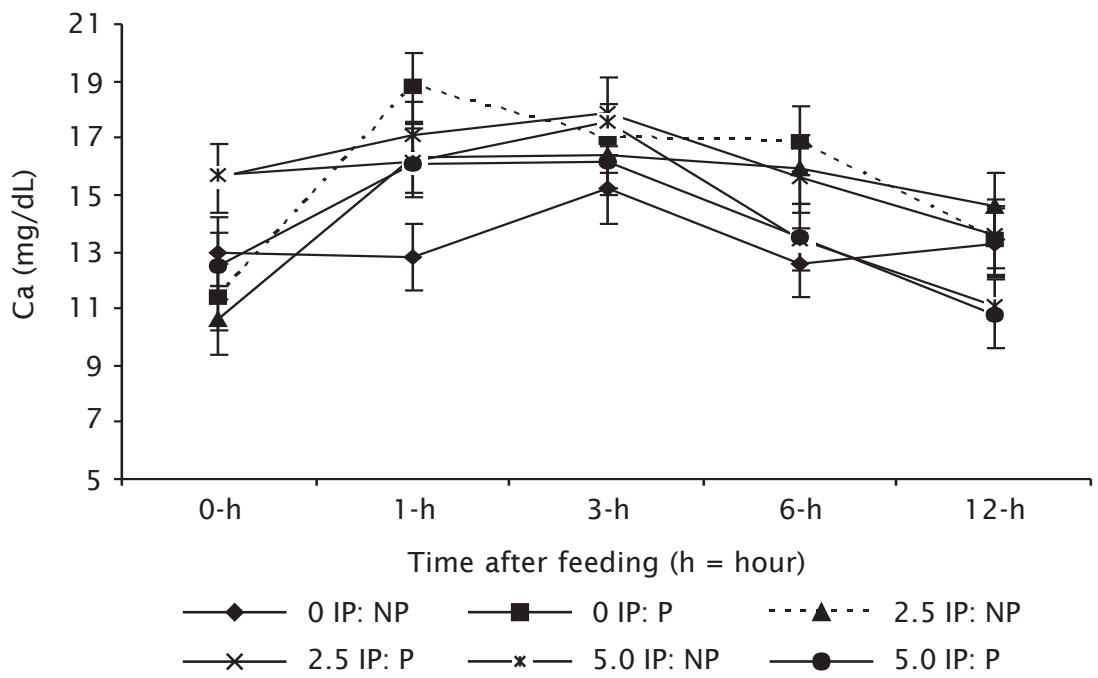

Figure 2. Change of postprandial plasma Ca of Japanese flounder fed different levels of dietary IP and phytase supplementation over 12-h. Each poin represents the mean values $( \pm \mathrm{SE})$ of three samplings of each treatment

ganic sources of fishmeal, krill meal and SPI in diet is not effectively digested by fish. The main form of dietary $P$ in fish diet is hydroxyapatite or bone phosphate which requires strong acidity to be solubilized in the stomach for subsequent absorption in the intestine (Sugiura et al., 2006). This may be the reason why $P$ in fishmeal is well-digested by mammals (Soares Jr, 1995) which have very low post-prandial stomach pH of 2 or less (Benne \& Levy, 2000) and poorly digested by fish (Cho \& Bureau, 2001). Moreover, fish cannot effectively utilize the P associated to IP6 coming from SPI since phytase was not included in this group. Significant higher plasma IP level in fish fed dietary IP which was clearly shown at 3-h postfeeding time revealed that availability of $P$ from inorganic source is more available than organic source. Resent study dealing with yellow tail reported that sodium phosphate monobasic as used in this experiment had much higher digestibility compared to tribasic form which is similar to phosphate form in fishmeal (Sarker et al., 2009). Furthermore, presence of phytase in diet significantly elevated the plasma IP level particularly at 6 -h post-feeding time indicating the higher $\mathrm{P}$ availability originated from IP6 after being degraded by phytase. At 6-h blood sampling, supplementation of phytase in diet contained $0.25 \%$ IP had significant higher peak value than fish fed no dietary IP, but did not further improve when dietary IP increased to $0.5 \%$.

Generally, P metabolism in fish is thought to be similar to that in mammals. Sugiura et al. (2003) reported that IP is transported by IP transporter in the apical membrane of intestinal cells, as well as paracellular transporter-independent pathways, and subsequently transported into plasma. Thus, IP that is not absorbed by intestine is secreted in feces. If it is not reabsorbed by IP transporter in the renal proximal tubule, plasma IP diffuses into urine in kidney and is excreted with the urine. In the present study, even though intestinal P absorption was not directly measured, higher plasma IP level in fish fed diet with phytase supplement provided evidence for a faster $P$ uptake in the digestive tract of fish compared to unsupplemented groups. To our knowledge, only one study is so far available reporting the post-feeding time course of IP in blood plasma of Nile tilapia (Liebert \& Portz, 2007). The authors found that following the highest dietary phytase at 1000 and $1250 \mathrm{FTU} / \mathrm{kg}$ diet, blood sampling at 2-h showed a similar response on plasma IP as the control diet contained IP supplement and become more pronounced at 4-h post-feeding time. In addition, they observed that the peak of plasma IP level oc- 


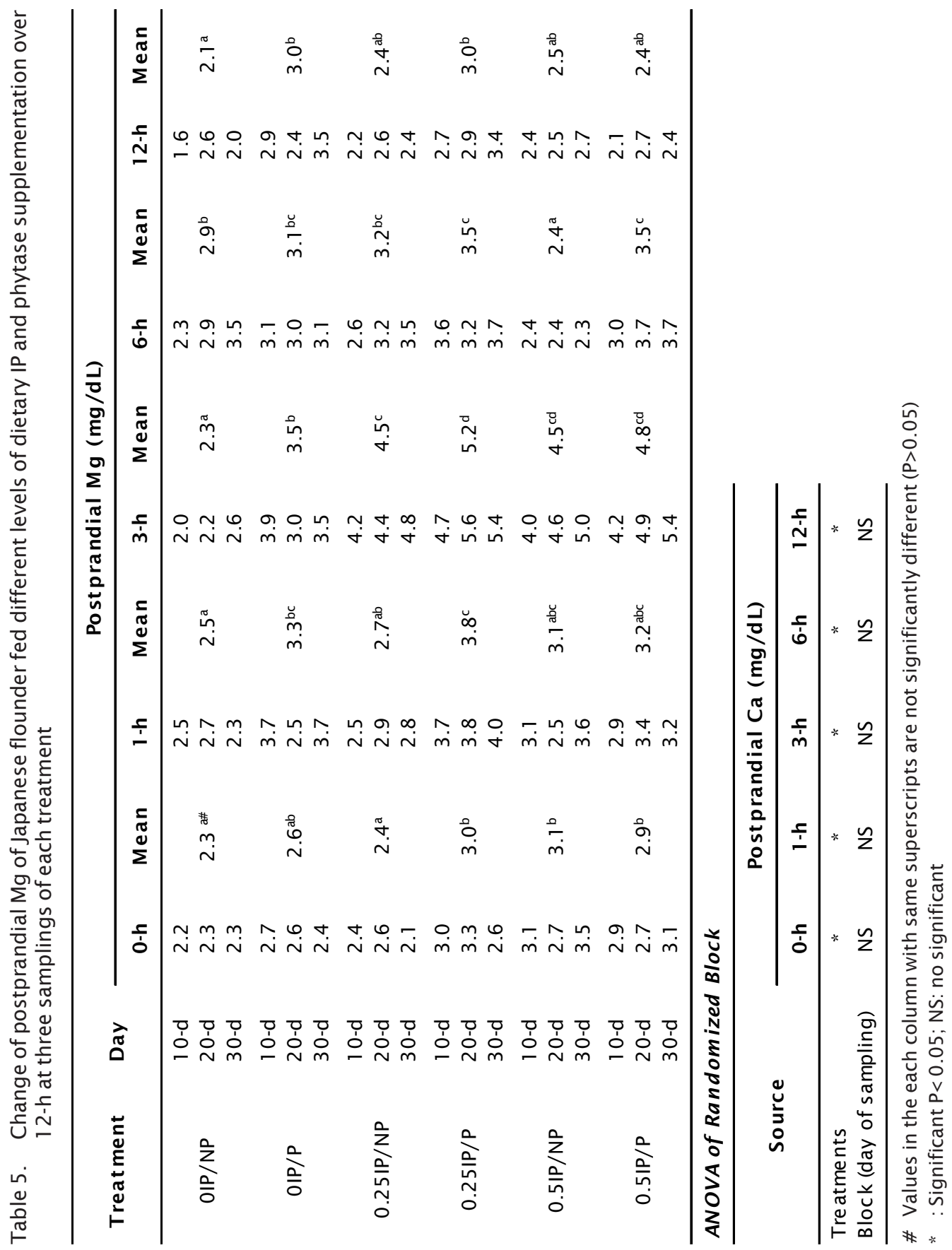




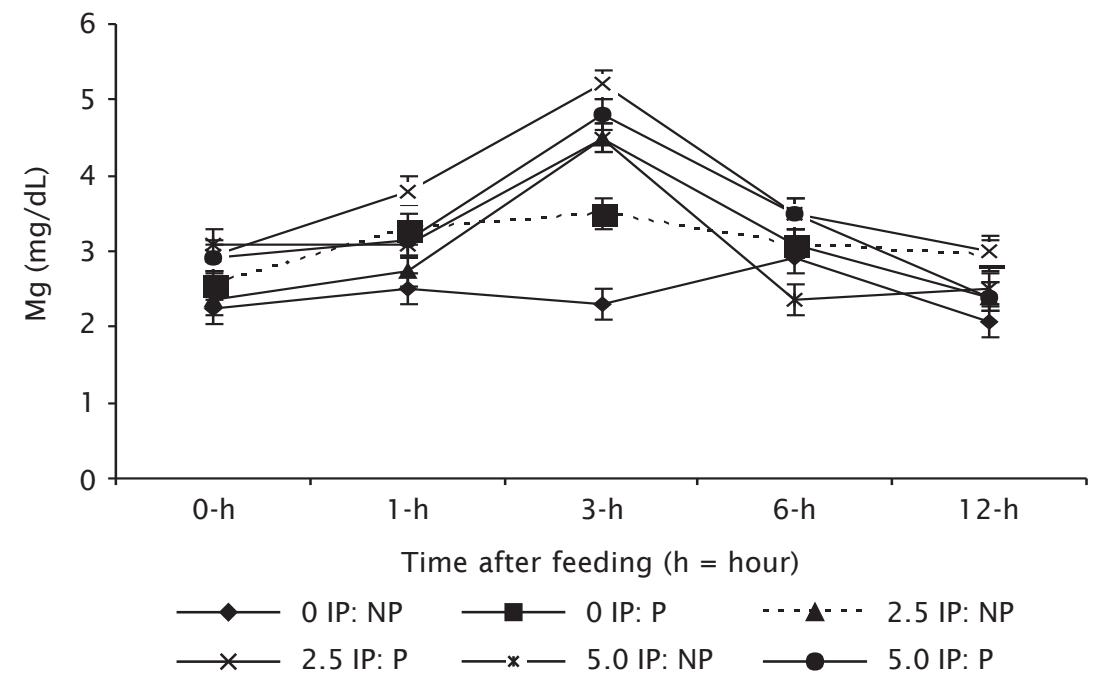

Figure 3 . Change of postprandial plasma Mg of Japanese flounder fed different levels of dietary IP and phytase supplementation over 12-h. Each poin represents the mean values $( \pm$ SE) of three samplings of each treatment

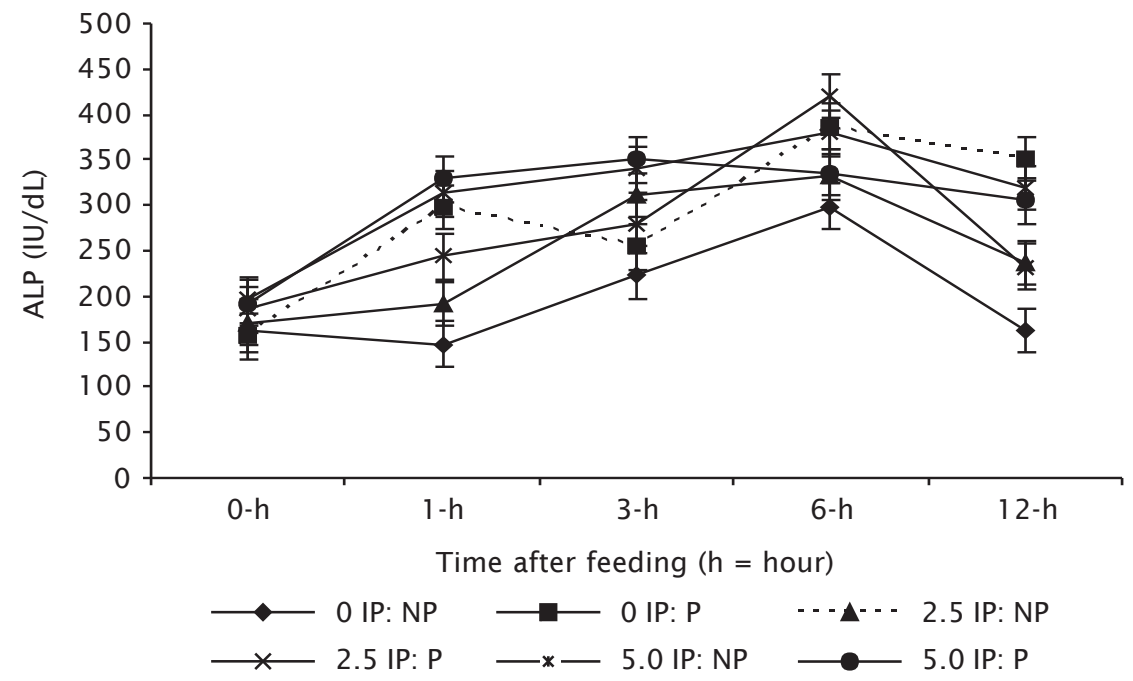

Figure 4. Change of postprandial plasma ALP of Japanese flounder fed different levels of dietary IP and phytase supplementation over 12-h. Each point represents the mean values $( \pm$ SEM) of three samplings of each treatment

curred at 8-h post-feeding and tended to exceed the effect of feeding control IP diet. Nile tilapia seemed to require lower phytase level to achieve the peak of plasma IP level compared to Japanese flounder as indicated in this study.
Based on statistical analysis, sampling days which reflected the fish age did not significantly affect the plasma IP level. Satoh et al. (2002) reported that in rainbow trout, P absorption from fishmeal decreased slightly as body weight increased. This was in contrast to $P$ 


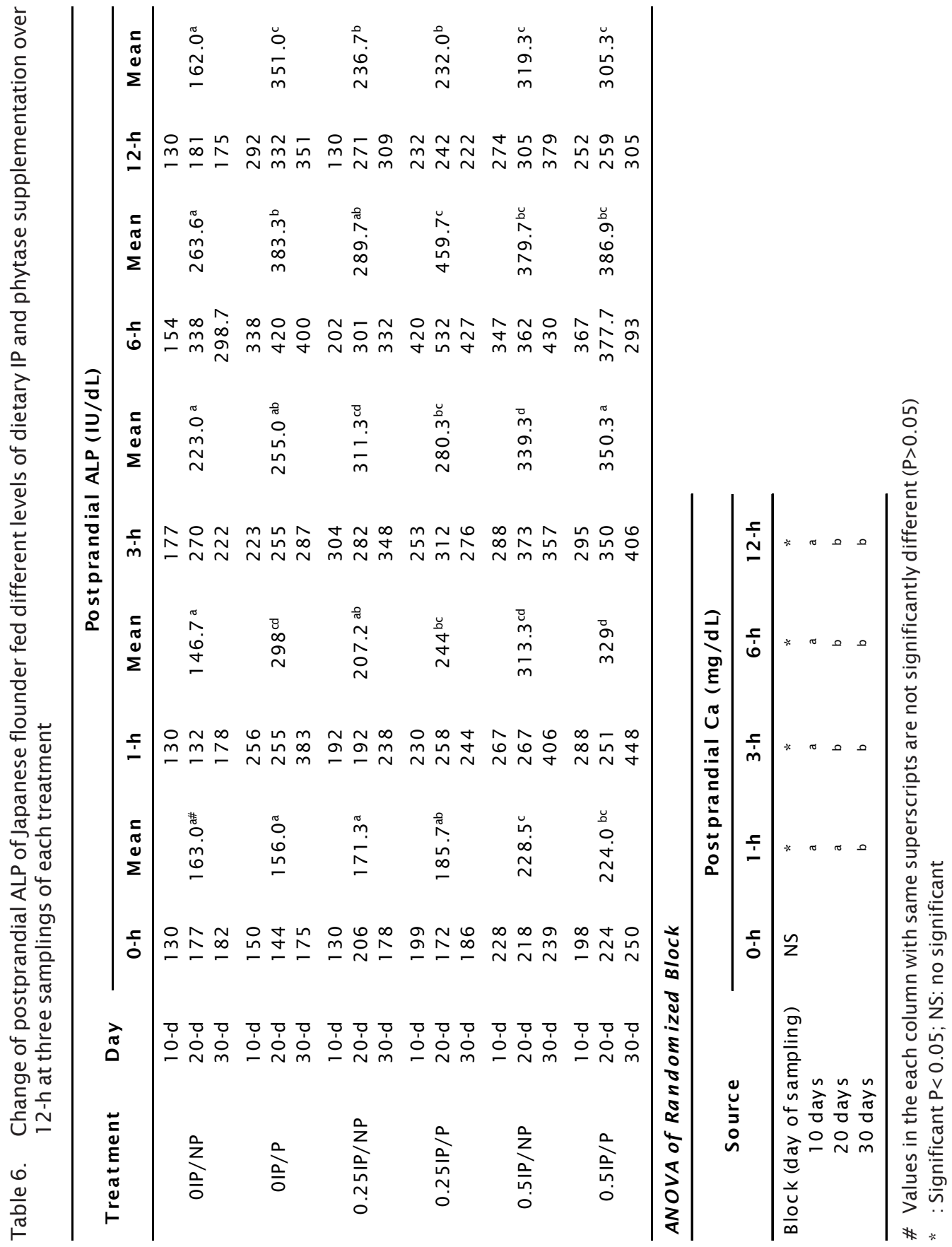


Table 7. Liver total P content of Japanese flounder before (0-h) and after 6 -h and $12-\mathrm{h}$ feeding diet containing different levels of dietary IP and phytase supplementation at three sampling days

\begin{tabular}{|c|c|c|c|c|c|c|c|}
\hline \multirow{2}{*}{ Treat ment } & \multirow{2}{*}{ Day } & \multicolumn{6}{|c|}{ Liver total $P$ cont ent } \\
\hline & & 0-h & Mean & 6-h & Mean & $12-\mathrm{h}$ & Mean \\
\hline \multirow{3}{*}{ OIP/NP } & $10-d$ & 1.02 & & 0.91 & & 1.04 & \\
\hline & $20-d$ & 1.06 & $1.08^{\mathrm{a}^{*}}$ & 1.06 & $1.02^{\mathrm{a}}$ & 1.17 & $1.12^{\mathrm{a}}$ \\
\hline & $30-d$ & 1.18 & & 1.08 & & 1.14 & \\
\hline \multirow{3}{*}{ OIP/P } & $10-d$ & 1.04 & & 1.09 & & 1.10 & \\
\hline & $20-d$ & 1.03 & $1.09^{a}$ & 1.18 & $1.13^{\mathrm{ab}}$ & 1.19 & $1.15^{\mathrm{ab}}$ \\
\hline & $30-d$ & 1.21 & & 1.12 & & 1.17 & \\
\hline \multirow{3}{*}{$0.25 \mathrm{IP} / \mathrm{NP}$} & $10-d$ & 1.09 & & 1.08 & & 1.12 & \\
\hline & $20-d$ & 1.17 & $1.15^{a b}$ & 1.09 & $1.12^{\mathrm{ab}}$ & 1.15 & $1.16^{\mathrm{ab}}$ \\
\hline & $30-d$ & 1.19 & & 1.21 & & 1.20 & \\
\hline \multirow{3}{*}{$0.25 \mathrm{IP} / \mathrm{P}$} & $10-d$ & 1.06 & & 1.06 & & 1.07 & \\
\hline & $20-d$ & 1.24 & $1.06^{\mathrm{ab}}$ & 1.29 & $1.16^{\mathrm{b}}$ & 1.21 & $1.17^{\mathrm{ab}}$ \\
\hline & $30-d$ & 1.17 & & 1.13 & & 1.22 & \\
\hline \multirow{3}{*}{$0.5 \mathrm{IP} / \mathrm{NP}$} & $10-d$ & 1.13 & & 1.04 & & 1.18 & \\
\hline & $20-d$ & 1.27 & $1.13^{b}$ & 1.3 & $1.15^{b}$ & 1.29 & $1.23^{c}$ \\
\hline & $30-d$ & 1.28 & & 1.11 & & 1.23 & \\
\hline \multirow{3}{*}{$0.5 \mathrm{IP} / \mathrm{P}$} & $10-d$ & 1.16 & & 1.11 & & 1.19 & \\
\hline & $20-d$ & 1.26 & $1.22^{b}$ & 1.29 & $1.21 \mathrm{~b}$ & 1.19 & $1.22^{b c}$ \\
\hline & $30-d$ & 1.25 & & 1.24 & & 1.27 & \\
\hline
\end{tabular}

ANOVA of Randomized Block

\begin{tabular}{cccc}
\hline \multirow{2}{*}{ Source } & \multicolumn{3}{c}{ Post-prandial ALP $(\mathrm{IU} / \mathbf{d L})$} \\
\cline { 2 - 4 } & $\mathbf{0 - h}$ & $\mathbf{6 - h}$ & $\mathbf{1 2 - h}$ \\
\hline Treatments & $\mathrm{S}$ & $\mathrm{S}$ & $\mathrm{S}$ \\
Block (day of sampling) & $\mathrm{S}$ & $\mathrm{S}$ & $\mathrm{S}$ \\
10 days & $\mathrm{a}^{*}$ & $\mathrm{a}$ & $\mathrm{a}$ \\
20 days & $\mathrm{b}$ & $\mathrm{b}$ & $\mathrm{b}$ \\
30 days & $\mathrm{b}$ & $\mathrm{b}$ & $\mathrm{b}$ \\
\hline
\end{tabular}

* Values in the each column with same superscripts are not significantly different $(P>0.05)$

$\mathrm{S}$ : Significant $\mathrm{P}<0.05$

absorption from plant ingredients which increased as fish weight increased to $10 \mathrm{~g}$ and then did not increase further in larger fish.

Different from the trend of postprandial plasma IP level, effect of phytase in increasing plasma Ca level was found only when dietary IP was not supplemented in diet. On the other hand, at higher dietary IP level, phytase supplementation did not significantly elevate plasma
Ca levels in all post-feeding time. In case of plasma Mg level, similar to plasma IP level, there was a clear trend of change of plasma $\mathrm{Mg}$ level at 1 and 3 -h postprandial period due to the phytase supplementation. It is likely that $\mathrm{Mg}$ seemed to be more associated with the IP6 complex than Ca in Japanese flounder. This is in accordance with the previous studies on the dose-response relationship between di- 
etary IP6 and mineral utilization using similar species that inclusion of dietary IP6 up to 13.5 $\mathrm{g} / \mathrm{kg}$ diet did not significantly decrease the plasma Ca level (Laining et al., 2010d). Similar finding was reported on Atlantic salmon that increasing of IP6 inclusion resulted in a progressive decrease of digestibility of $\mathrm{Mg}$ and Zn (Denstadli et al., 2006). In contrast, Papatryphon et al. (1999) found that Ca was more associated with the phytate complex than other minerals in striped bass.

Post-prandial plasma ALP at 6-h period was strongly related to plasma IP level at the same post-feeding time. Regardless the dietary phytase, inclusion of dietary IP at $0.25 \%$ had a similar plasma ALP level to those fed diet without IP except at 3-h post-feeding time. However, increase of dietary IP to $0.5 \%$ significantly elevated plasma ALP level in all post-feeding time. In addition, plasma ALP significantly elevated by sampling days in all post-feeding time except at pre-feeding time. It is not known yet whether a relationship existed between the plasma ALP level and the activity of the digestive enzymes.

Even though ALP plays role in the absorption of several minerals in particular $\mathrm{P}$ and $\mathrm{Ca}$ for bone mineralization (Eguchi, 1995), effect of dietary IP and phytase supplement on plasma ALP in fish is so far still contradictory. Shearer $\&$ Hardy (1987) reported plasma ALP activity in rainbow trout was not significantly affected by feeding phosphorus sufficient and deficient diet. Since the importance of plasma ALP in fish nutrition, it is necessary to assess their variability with respect to physiological or environmental factors and determine the normal ranges of variation under different levels of such factors.

According to Lall (2002), absorbed P accumulates in skeletal tissue and soft tissue including liver, kidney, heart, muscle and blood. At pre and post-prandial liver P content, dietary $0.5 \%$ IP at two levels of phytase supplement significantly increased liver $P$ content particularly at 12 -h post-feeding time. Similar to plasma ALP level, accumulation of $P$ in liver $P$ seemed to be influenced by the sampling days which reflected the age of fish.

Change of 12-h postprandial $\mathrm{Ca}, \mathrm{Mg}$ and ALP in other species after feeding dietary IP and phytase is extremely scarce. These preliminary results of blood sampling are useful as additional information corresponding to varying effects depending on the dietary IP and phytase levels fed to Japanese flounder.

\section{CONCLUSION}

Post-prandial plasma IP, Ca, Mg and ALP levels after 12-h feeding was lower in fish fed diet contained no dietary IP and phytase supplement. Supplementation of phytase at 0.25 and $0.5 \%$ IP had similar plasma IP, Mg and ALP levels at 6 -h post-feeding. Maximum level of plasma IP and ALP appeared at 6-h post-feeding in fish fed diet supplemented with $0.25 \%$ IP together with phytase. Peak of plasma Mg level occurred at 3 -h post-feeding in fish fed diet contained $0.25 \%$ IP together with phytase.

\section{ACKNOWLEDGMENT}

The first author would like to thank the Ministry of Education, Culture, Sport, Science and Technology (Monbukagakusho), Japan for the financial support.

\section{REFERENCES}

Angel, R., Tamim, N.M., Applegate, T.J., Dhandu, A.S., \& Ellestad, L.E. 2002. Phytic acid chemistry: influence on phytin-phosphorus availability and phytase efficacy. Journal of Applied Poultry Res., 11: 471480.

Argenzio, R.A. \& Southworth, M. 1975. Sites of organic acid production and absorption in gastrointestinal tract of the pig. American Journal of Physiology, 228: 454-460.

Benne, R.M. \& Levy, M.N. 2000. Principles of Physiology ( $3^{\text {rd }}$ edn). Philadelphia. Mosby.

Cho, C.Y. \& Bureau, D.P. 2001 . A review of diet formulation strategies and feeding systems to reduce excretory and feed wastes in aquaculture. Aquaculture Research, 32: 349-360.

Denstadli, V., Skrede, A., Krogdahl, Å., Sahlstrøm, S., \& T. Storebakken. 2006. Feed intake, growth, feed conversion, digestibility, enzyme activities and intestinal structure in Atlantic salmon (Salmo salar L.) fed graded levels of phytic acid. Aquaculture, 256: 365-376.

Eguchi, M. 1995. Alkaline phosphatase isoenzymes in insects and comparison with mammalian enzyme. Comparative Biochemistry and Physiology, $111 \mathrm{~B}$ : 151-162. 
Kemme, P.A., Jongbloed, A.W., Mroz, Z. \& Beynen, A.C. 1998: Livest. Prod. Sci., 54: 33-44.

Kemme, P.A., Schlemmer, U., Mroz, Z. \& Jongbloed, A.W. 2006. Monitoring the stepwise phytate degradation in the upper gastrointestinal tract of pigs. Journal of Science of Food and Agriculture, 86: 612-622.

Laining, A., Koshio, S., \& Rachmansyah. 2010 a. Interaction between dietary phosphorus and phytase supplement on growth, feed intake and vertebral mineral content of juvenile Japanese flounder, Paralichthys olivaceus. Journal of Aqucultura Indonesiana (In Preparation).

Laining, A., Ishikawa, M., Kyaw, K., Gao, J., Binh, N.T., Koshio, S., Yamaguchi, S., Yokoyama, S., \& Kojima. J. 2010b. Dietary calcium: phosphorus ratio influences the efficacy of microbial phytase on growth, mineral digestibility and vertebral mineralization in juvenile tiger puffer, Takifugu rubripes. Aquaculture Nutrition (In Press).

Laining, A., Ishikawa, M., Koshio, S., Lideman, \& Yokoyama, S. 2010c. Growth, nutrient utilization and scoliosis syndrome in juvenile red sea bream, Pagrus major fed different levels of phosphorus and microbial phytase. Aquaculture Nutrition (In Preparation).

Laining, A., Traifalgar, R. F., Thu, M., Komilus, C.F., Kader, Md.A., Koshio, S., Ishikawa, M., \& Yokoyama, S. $2010 \mathrm{~d}$. Influence of dietary phytic acid on growth, feed intake and nutrient utilization in juvenile Japanese flounder, Paralichthys olivaceus. Journal of World Aquaculture Society (In press).

Lall, S.P. 2002. The minerals. In: Halver, J.E., Hardy, R.W. (Eds.), Fish Nutrition, 3rd ed. Academic Press, San Diego, CA, pp. 259308.

Liebert, F. \& Portz, L. 2007. Different sources of microbial phytase in plant based low phosphorus diets for Nile tilapia Oreochromis niloticus may provide different effects on phytate degradation. Aquaculture, 267: 292-299.

Lowry, O.H. \& Lopez, J.A. 1946. Determination of inorganic phosphate in the presence of labile phosphate esters. J. of Biol. Chem., 162: 421-428.

Papatryphon, E., Howell, R.A. \& Soares Jr, J.H. 1999. Growth and mineral absorption by striped bass Morone saxatilis fed a plant feedstuff based diet supplemented with phytase. J. of World Aquaculture Society, 30 No.2: 161-173.

Phillippy, B.Q. 2001 . Stability of plant and microbial phytases. In: Reddy NR, Sathe SK, editors. Food phytates. Lancaster, Pa.: Technomic. Forthcoming, p.110-129.

Pontoppidan, K., Pettersson, D. \& Sandberg, A.S. 2007. Peniophora lycii phytase is stabile and degrades phytate and solubilises minerals in vitro during simulation of gastrointestinal digestion in the pig. Journal of the Science of Food and Agriculture, 87: 2,700-2,708.

Rodehutscord, M. \& Pfeffer, E. 1995. Effects of supplemental microbial phytase on phosphorus digestibility and utilization in rainbow trout (Onchorhynchus mykiss). Water Science Technology, 31: 143-147.

Sarra, P. G., Morelli, L., \& Bottazzi, V. 1992. The lactic microflora of fowl. In: B. J. B. Wood (ed.), The lactic acid bacteria in health and disease, Vol. 1. Elsevier Applied Science, London, United Kingdom, p. 3-19.

Sarker, P.K., Fukada, H., \& Masumoto, T. 2009. Phosphorus availability from inorganic phosphorus sources in yellowtail (Seriola quinqueradiata Temminck and Schlegel). Aquaculture, 289: 113-117.

Satoh, S., Takanezawa, M., Akimoto, A., Kiron, V. \& Watanabe, T. 2002. Changes of phosphorus absorption from several feed ingredients in rainbow trout during growing stages and the effect of extrusion of soybean meal. Fisheries Science, 68: 325-331.

Selle, P.H. \& Ravindran, V. 2007. Microbial phytase in poultry nutrition (Review). Animal Feed Science and Technology, 135: 1-41.

Seynaeve, M., Janssens, G., Hesta, M., Nevel, V.C., \& De Wilde, R.O. 2000. Effects of dietary $\mathrm{Ca} / \mathrm{P}$ ratio, $\mathrm{P}$ level and microbial phytase supplementation on nutrient digestibilities in growing pigs: precaecal, post-ileal and total tract disappearances of $\mathrm{OM}, \mathrm{P}$ and $\mathrm{Ca}$. Journal of Physiology and Animal Nutrition, 83: 36-48.

Shearer, K.D. \& Hardy, R.W. 1987. Phosphorus deficiency in rainbow trout fed a diet containing deboned fillet scrap. Progressive Fish-Culture, 49: 192-197.

Soares, J.H., Jr. 1995. Phosphorus availability. In: C.B. Ammerman, D.H. Baker and A.J. Lewis (ed.), Bioavailability of nutrients for animals. Academic Press, San Diego, CA., pp. 257-294. 
Sugiura, S.H., McDaniel, N.K., \& Ferraris, R.P. 2003. In vivo fractional $\mathrm{Pi}$ absorption and $\mathrm{NaPi}-\mathrm{II}$ mRNA expression in rainbow trout are unregulated by dietary $P$ restriction. American. Journal of Physiology, 285: R770R781.

Sugiura, S.H. \& Ferraris, R.P. 2004. Contributions of different $\mathrm{NaPi}$ cotransporter isoforms to dietary regulation of $P$ transport in the pyloric caeca and intestine of rainbow trout. Journal of Experimental Biology, 207: 2,055-2,064.
Sugiura, S.H., Roy, P.K., \& Ferraris, R.P. 2006. Dietary acidification enhances phosphorus digestibility but decreases $\mathrm{H}+/ \mathrm{K}+-\mathrm{AT}$ Pase expression in rainbow trout. J. Exp. Bio., 209: 3,719-3,728.

Yan, W. \& Reigh, R.C. 2002. Effects of fungal phytase on utilization of dietary protein and minerals and dephosphrylation of phytic acid in the alimentary tract of channel catfish, Ictalurus punctatus fed an allplant protein diet. Journal of World Aquaculture Society, 33: 10-22. 